\title{
REVIEW
}

\section{Biomining: an Established and Dynamic Biotechnology}

\author{
DAVID BARRIE JOHNSON
}

\author{
College of Natural Sciences, Bangor University, Bangor LL57 2UW, United Kingdom
}

\begin{abstract}
"Biomining" is generic term to describe the application of living organisms to extract and recover metals from mineral ores and waste materials. Since its inception as a crude technology ("dump leaching”) for treating "run of mine" rocks and boulders that contained too little copper to be processed by conventional processing, engineering options used in biomining have become increasingly refined and diverse. Currently, microbiological processing is used to extract both base metals (copper, and to lesser extents nickel and zinc) and precious metals (mostly gold) from ores and mineral concentrates in heaps and stirred-tank bioreactors, as well as in dumps. Recent developments include the demonstration, at pilot-scale, of indrect leaching of zinc sulfide concentrates, in which the biological step (regeneration of ferric iron) is carried out independently of abiotic mineral oxidation, and using microbiologically-mediated reductive dissolution of ferric iron minerals to liberate nickel from lateritic ores.
\end{abstract}

Keywords: biomining, microbiological process

"Biomining" adalah istilah umum yang digunakan untuk menggambarkan penggunaan organisme hidup untuk mengekstrak dan memisahkan logam dari bijih mineral dan limbah. Biomining pada awalnya dikenal sebagai teknologi untuk mengolah bahan tambang berupa batu-batuan yang memiliki kandungan tembaga yang terlalu sedikit yang tidak mampu diolah menggunakan prosedur konvensional, tetapi penerapan teknologi ini secara perlahan meningkat dan meluas. Saat ini, aplikasi mikroorganisme dalam pertambangan digunakan untuk mengekstraksi baik logam dasar (tembaga dan logam yang memiliki nilai yang lebih rendah seperti nikel dan zink) maupun logam mulia (terutama emas) dari bijih logam dan konsentrat mineral yang diolah dalam tangki bioreaktor. Pengembangan teknologi ini telah diterapkan dalam skala besar untuk memurnikan konsentrat zink sulfida, dimana dalam tahapannya regenerasi besi ferri dilakukan tanpa menggunakan senyawa abiotik pengoksidasi mineral, tetapi pelarutan reduktif mineral besi ferri secara mikrobiologi sehingga nikel dapat dimurnikan dari bijih tambang.

Keywords: biomining, proses mikrobiologi

\section{Evolution of Biomining as a Niche Technology for Mineral Processing}

The idea that microorganisms could be used to extract metals from sulfidic ore arose from the discovery in the late 1940's of a bacterium that was able to generate ferric iron from ferrous in acidic liquors, and subsequent demonstrations that this microorganism could grow autotrophically on pyrite and other sulfide minerals, causing their dissolution. Thiobacillus ferrooxidans, as it was known at the time (it was renamed Acidithiobacillus (At) ferrooxidans in 2000) has been one of the most widely studied of all bacteria outside of those of medical importance. While other acidophilic bacteria and archaea can also degrade sulfide minerals in pure or mixed cultures, the early work with At. ferrooxidans remains an important foundation stone for the entire biomining industry.

*Corresponding author; Phone: +44-01248382358; E-mail: d.b.johnson@bangor.ac.uk
The first recognized application of biomining was by the Kennecott Copper Corporation in the 1950's who obtained a patent for using bacteria to extract copper from their waste rock dumps and developed operations at the Bingham Canyon mine in Utah and later at the Chino mine in New Mexico (Fig 1). Since then, mine operations using dump bioleaching of low-grade copper ore have been established world-wide. Gradation from dump to heap leaching (described below) began with the use of "thin layer" engineering of mounds (crushed ore, stacked 2.5 to $6 \mathrm{~m}$ in height) at the Lo Aguirre mine, and later demonstration of the benefits of forced aeration of heaps at the Quebrada Blanca mine (both copper mines, located in Chile; Brierley 2008). Heap bioreactors used to recover metals other than copper have been established in Nevada (since 1999; pretreatment of refractory gold ore) and Finland (since 2008; bioleaching of a polymetallic black schist at the Talvivaara mine, extracting nickel, zinc, and copper). Stirred tank bioreactors processing sulfidic ores have 
been operating since 1986. Most of these are used to oxidize arsenopyrite and pyrite that are present in refractory gold ores, thereby liberating otherwise occluded fine particles of the precious metal. The first plant to be commissioned, at the Fairview Mine in Barberton, South Africa, is still in operation today. Its design capacity (55 t/day) has far been exceeded by more recent plants established in Western Australia (Wiluna; 158 t/d), China (Jinfeng; 790 t/d), Ghana

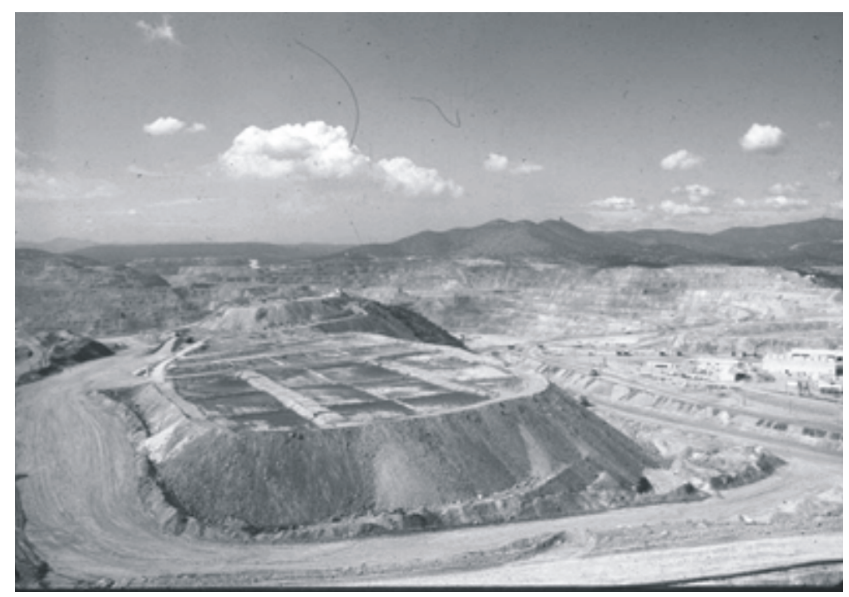

Fig 1 Dump leaching of "run-of-mine" ore at the Kennecott Chino mine, New Mexico.

(Ashanti; $960 \mathrm{t} / \mathrm{d}$ ) and elsewhere (Brierley 2008). One of the more recent stirred tank bioleaching systems to have been commissioned (at Kokpatas, Uzbekistan) is designed to process over $160,000 \mathrm{t}$ of refractory gold concentrate each day.

\section{Engineering Designs and Operational Parameters}

Currently, there are two major engineering variants for biomining-irrigated systems and stirred tanks. In the first of these, low grade sulfidic rocks (ranging from large boulders to ground and agglomerated ore) are piled into large dumps or heaps, which are then irrigated with an acidic liquor to stimulate the activities of microorganisms that either occur naturally with the ore or else are inoculated into the heaps. The percolating liquor becomes enriched with metals (and sulfate) released from the sulfide minerals and also other minerals (referred to as gangue minerals) that are unstable in acidic solutions. This "pregnant leach solution" (PLS) is collected from outflow channels from the base of the dump or heap, and the target metal(s) extracted. Dump leaching was the first practice of biomining to be adopted, and is still operated at many mines to extract copper from low-grade "run of mine" ores that contain too little of the metal (typically $<0.5 \%$ by weight) to merit conventional processing (grinding, concentrating and smelting). Heap leaching (Fig 2) is a more refined approach for bio-processing low-grade mineral ores, concentrates heap leaching, which entrails agglomeration of the concentrate onto a coarse substrate, has been investigated. The main differences between heap and dump leaching systems are: (i) ores chrushed to facilitate more rapid breakdown of sulfide minerals and, where fine-grain particles are produced, these may be agglomerated with sulfuric acid; (ii) the heaps themselves are generally smaller in height (typically 6$10 \mathrm{~m}$ ) than are dumps (though their base areas may exceed those of dump operations) and several successive heaps (or "lifts") may be stacked upon each other as the operation develops; (iii) heaps are often aerated from beneath as well as irrigated from above, to provide the primary autotrophic mineral-oxidizing microorganisms with both oxygen and carbon dioxide; (iv) heaps are constructed on pads that are lined with impermeable synthetic liners (generally high density polyethylene on which drain pipes, used to collect and convey PLS, are placed); (v) inoculation ponds, in which mineraldegrading bacteria and archaea can be grown to high cell densities and then introduced either in the irrigation liquor or else during the mineral agglomeration process, may be used in heap operations. The higher capital cost expenditure results in more rapid (heaps typically operate for about a year) and more extensive (up to $90 \%$ )

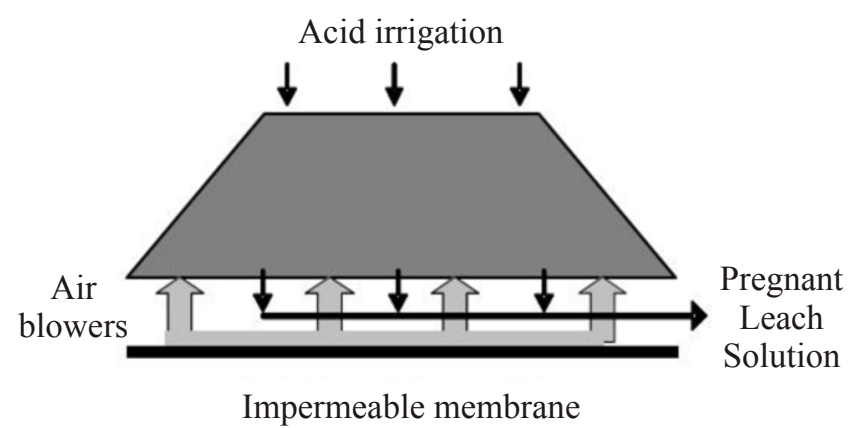

Fig 2 Schematic of a heap leaching operation.

metal extraction than is achieved in dump operations. Again, the main metal that is recovered in heap biomining operations is copper, though a polymetallic black schist ore (where the major metal in terms of its economic value is nickel) is currently processed via heap leaching in Finland, and heap leaching of a refractory gold ore was operated for over a decade in a site in Nevada (Brierley 2007).

Bioprocessing of sulfidic mineral concentrates in 
stirred tanks that are continually aerated and maintained at prescribed temperatures and $\mathrm{pH}$ values constitute the most efficient biomining systems currently in operation, in terms of both speed and efficiency of the operation. However, the greater costs involved in constructing and maintaining the vast bioreactors used (each up to $1,350 \mathrm{~m}^{3}$-the largest reactors used for any biological-based operation) means that these have been operated as full-scale commercial systems for recovering gold rather than base metals, with the single exception of a bioleaching plant in Uganda where cobalt is the target metal. Most commercial stirred tank biomining systems operate at $\mathrm{pH}$ of about 1.5 and temperatures between 40 and 45 ${ }^{\circ} \mathrm{C}$. Since the oxidative dissolution of sulfide minerals is an exothermic reaction, cooling rather than heating of the tanks is required, constituting (along with stirring of the dense mineral slurries $-20 \%$ pulp density is typical) a significant part of the running costs of any single operation.

\section{Mechanisms of Oxidative Dissolution of Minerals by Microorganisms}

The mechanism(s) by which microorganisms catalyze the oxidative dissolution of sulfide minerals has been the subject of considerable debate for many years. Minerals, such as pyrite, are stable in environments that are totally dry or from which oxygen is excluded. In biomining operations, where solution $\mathrm{pH}$ is generally $<2.5$, soluble ferric iron is the main oxidant of sulfide minerals, as illustrated (for pyrite) in equation [1]:

$$
\mathrm{FeS}_{2}+6 \mathrm{Fe}^{3+}+3 \mathrm{H}_{2} \mathrm{O} \rightarrow 7 \mathrm{Fe}^{2+}+\mathrm{S}_{2} \mathrm{O}_{3}^{2-}+6 \mathrm{H}^{+}
$$

Ferric iron is consumed in this reaction and its, regeneration is primarily mediated (except in very high temperature liquors) by iron-oxidizing bacteria and archaea, in an oxygen-requiring reaction [2]:

$$
\mathrm{Fe}^{2+}+0.25 \mathrm{O}_{2}+\mathrm{H}^{+} \longrightarrow \mathrm{Fe}^{3+}+0.5 \mathrm{H}_{2} \mathrm{O}
$$

Sulfide minerals can be divided into those that are acid-soluble (e.g. sphalerite, chalcopyrite, arsenopyrite and galena) and others that are not susceptible to proton attack (e.g. pyrite, molybdenite and tungstenite $\left(\mathrm{WS}_{2}\right)$. In acidic liquors, the latter are oxidized by soluble ferric iron, and a total of six successive one-electron oxidation steps are required to break the sulfur-metal bonds. Since the initial sulfur product released from the degrading mineral is thiosulfate, this form of oxidative sulfide mineral dissolution has been described as the "thiosulfate mechanism" (Rohwerder et al. 2003). Thiosulfate is unstable in acidic liquors (more so when ferric iron is present) and oxidizes via tetrathionate and other sulfur oxy-anions, ultimately to sulfate.

\section{The Microbiology of Biomining Operations}

Microorganisms that are involved in biomining operations have been described in a number of reviews (e.g. Schippers 2007); Rawlings and Johnson 2007b. Acidophiles that can have either a direct or indirect process in the dissolution of sulfide minerals can be categorized as primary, secondary and tertiary microorganisms. Primary bacteria and archaea are those chemo-autotrophs that can catalyze ferrous iron oxidation, and thereby initiate mineral oxidation; secondary microorganisms are sulfur-oxidizers that generate the acidity required for the acidophilic consortia, while tertiary acidophiles are those that degrade organic compounds excreted from living bacteria (most of which in biomining operations are autotrophic) or lysed from dead cells, and thereby help maintain suitable conditions for the more "organic sensitive" lithotrophs, such as Leptospirillum spp.. In reality, there is considerable overlap between these categories. For example, some Acidithiobacillus spp. (At. ferrooxidans and At. ferrivorans) can oxidize both ferrous iron and reduced sulfur as can all Sulfobacillus spp., and some heterotrophic acidophiles (e.g. Ferrimicrobium acidiphilum and Ferroplasma spp.) can also oxidize iron as can some mixotrophic acidophiles (e.g. Acidimicrobium ferrooxidans). Primary producers in stirred tank operations are exclusively chemolithoautotrophic bacteria. Another important characteristic that can be use to differentiate acidophilic bacteria and archaea is their response to temperature. A pragmatic and much-used distinction has been made between (extreme) thermophiles, that have temperature optima above $60^{\circ} \mathrm{C}$, moderate thermophiles $\left(40-60{ }^{\circ} \mathrm{C}\right)$ and mesophiles $(20$ $40{ }^{\circ} \mathrm{C}$ ). Archaea account for almost all of the first group, most moderate acidophiles are Gram-positive bacteria, and Gram-negative bacteria make up the majority of mesophilic species.

Although oxidative dissolution of simple and complex sulfide ores and concentrates may be mediated by pure cultures of iron-oxidizing acidophiles, as has often been described in laboratory studies, axenic cultures are never found in actual 
biomining operations. Consortia of microorganisms with synergistic (and sometimes complimentary) metabolic physiologies, have been identified in all commercial-scale systems that have been examined. Laboratory studies using defined populations of acidophiles have demonstrated that mixed cultures are more robust and are also frequently superior to pure cultures in terms of leaching kinetics.

All biomining operations necessarily operate as open and non-sterile systems. However, because of the prevailing conditions, only living organisms that are able to survive in environments that are both highly acidic and that contain greatly elevated concentrations of toxic metals and other dissolved solutes are active in biomining operations, which restricts indigenous life forms almost exclusively to some "extremophilic" bacteria and archaea. Metal extraction occurs due to the oxidative dissolution of sulfide minerals in which the metals either occur (e.g. in the case of copper) or else are associated (e.g. in the case of gold) with sulfides, and the primary prokaryotes involved are autotrophic iron-oxidizers that continually regenerate the main oxidizing agent (ferric iron) that initiates mineral dissolution. However, microbial consortia rather than individual species are involved in mineral dissolution in both heaps and stirred-tanks. Autotrophic sulfuroxidizers generate sulfuric acid from reduced sulfur species that originate from the degraded sulfide minerals and, by so-doing, maintain the extremely low $\mathrm{pH}$ environment that promote both the activities of the iron-oxidizers and the effectiveness of ferric iron as an oxidizing agent. A third group of prokaryotic acidophiles that degrade organic carbon compounds that derive from active and dead carbon-fixing acidophiles contribute to the robustness and efficiency of the consortia by removing material that might otherwise inhibit the primary mineral-degraders. In recent years, the identities of acidophiles involved in pilot-scale and full-scale biomining operations have been revealed by the application of biomolecular techniques, while advances in techniques for isolating and cultivating physiologically and phylogenetically diverse acidophiles in the laboratory have facilitated understanding of the nature and importance of microbial interactions in biomining environments.

\section{Indirect Leaching of Metal Sulfide Concentrates}

One alternative engineering design option for biomining that has been demonstrated successfully at the pilot-scale is "indirect leaching". In this, the biological regeneration of ferric iron is separated from the oxidation of the target mineral by ferric iron (which is an abiotic reaction). In this way, it is possible to optimize conditions for the different reactions, e.g. the abiotic reaction is generally faster at elevated temperatures and does not require oxygen, in contrast to the biological process (Fig 3). Another advantage with this approach is that the sulfide moiety in the mineral can be oxidized to elemental sulfur, rather than sulfate.

\section{Bioprocessing of Oxidized Metal Ores by Reductive Dissolution}

At present, all biomining operations use sulfide ores, and metals are recovered by a process of oxidative dissolution of metal-bearing minerals. Some metal ores, however, are already oxidized (such as nickel laterites,

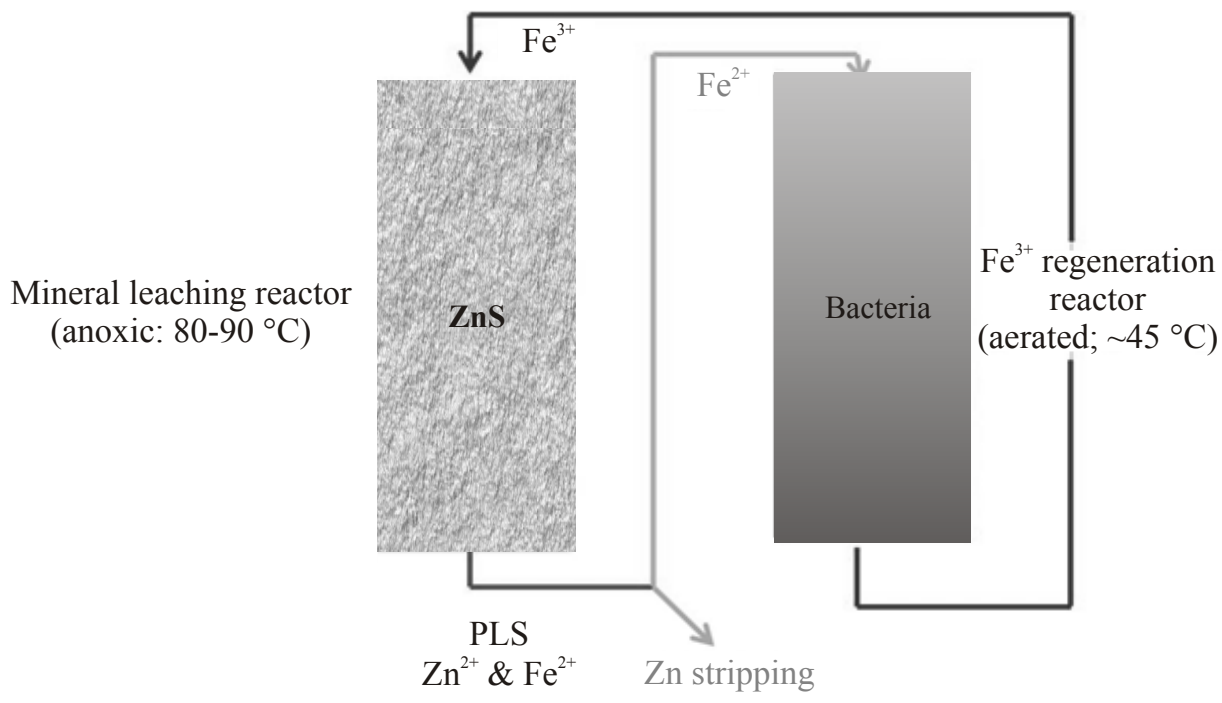

Fig 3 Schematic of the "indirect" bioleaching of zinc sulfide concentrate. 


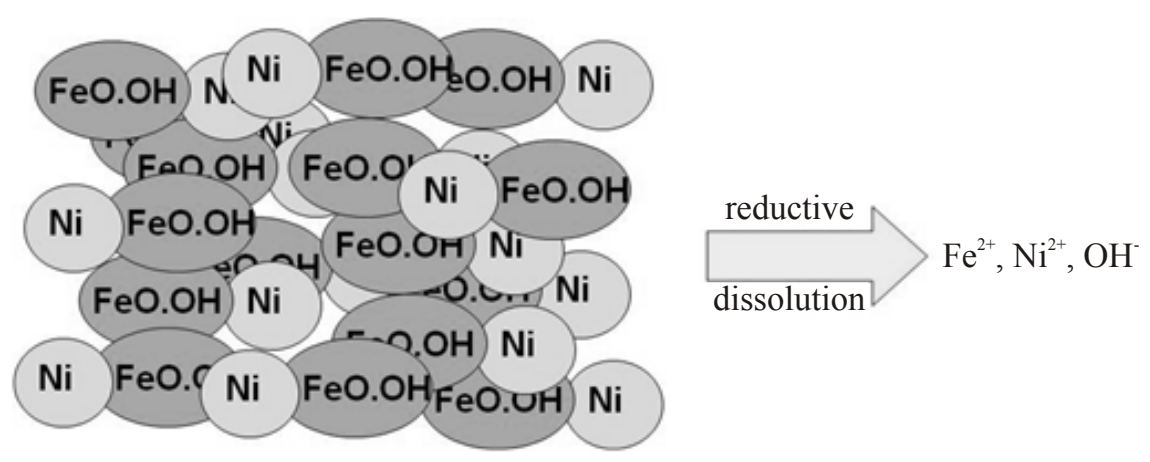

Fig 4 Nickel extracting from lateritic ores using specialised bacteria.

which represent about $70 \%$ of nickel ores in the lithosphere) and therefore such an approach cannot be used to process them. A novel technique has, however, recently been devised and demonstrated for extracting nickel from lateritic ores using specialised bacteria (Fig 4; Hallberg et al. 2011). In this, ground ore is mixed with elemental sulfur and inoculated with the acidophilic iron-reducing bacterium, At. ferrooxidans. When oxygen is depleted, the bacteria couple the oxidation of sulfur to the reduction of ferric iron present in goethite, which is the most abundant mineral in the ore and with which much of the nickel is intimately associated. The goethite is disrupted and ultimately destroyed in this process (known as "reductive mineral dissolution"), and the nickel is solubilised. Since the process operates in an acidic liquor $(\mathrm{pH} \sim 1.8)$ the nickel remains in solution, which facilitates its downstream recovery by ionexchange, solvent extraction/electrowinning or sulfide precipitation. This new approach to biomining demonstrates further the potential for using biological systems in "green" technologies relating to the mining industry.

\section{ACKNOWLEDGMENT}

The author is grateful to the Royal Society (U.K.) for the provision of an Industrial Fellowship.

\section{REFERENCES}

Brierley CL. 2008. How will biomining be applied in future? $\mathrm{T}$ Nonferr Metal Soc. 18(6):1302-1310. doi: 10.1016/S1003-6326(09)60002-9.
Brierley JA. 2007. A perspective on developments in biohydrometallurgy. Hydrometallurgy 94(1-4):2-7. doi: 10.1016/j.hydromet.2008.05.014.

Hallberg KB, Grail BM, Plessis C.du, DB Johnson. 2011. Reductive dissolution of ferric iron minerals: a new approach for bioprocessing nickel laterites. Miner Eng. 24(7): 620-624. doi: 10.1016/j.mineng.2010.09.005 .

Johnson DB. 2010. The biogeochemistry of biomining. In: Barton L, Mandl M, editors. Geomicrobiology: Molecular and environmental perspective. Dordrecht: Springer. p 401-426. doi: 10.1007/978-90-481-9204$5 \_19$.

Rawlings DE, Johnson DB. 2007a. Biomining. SpringerVerlag, Heidelberg. doi: 10.1007/978-3-540-34911-2.

Rawlings DE, Johnson DB. 2007b. The microbiology of biomining: development and optimization of mineraloxidizing microbial consortia. Microbiology 153(2): 315-324. doi: 10.1099/mic.0.2006/001206-0.

Rohwerder T, Gehrke T, Kinzler K, Sand W. 2003. Bioleaching review part A: Progress in bioleaching: fundamentals and mechanisms of bacterial metal sulfide oxidation. Appl Microbiol Biotechnol. 63(3): 239-248. doi: 10.1007/s00253-003-1448-7.

Schippers A. 2007. Microorganisms involved in bioleaching and nucleic acid-based molecular methods for their identification and quantification. In: Donati ER, Sand $\mathrm{W}$, editors. Microbial processing of metal sulfides. Dordrecht, The Netherlands, Springer. 3-33. doi: 10.1007/1-4020-5589-7_1. 